Federal Reserve Bank of Minneapolis Research Department

\title{
Entrepreneurship, Frictions and Wealth
}

\author{
Marco Cagetti and Mariacristina De Nardi* \\ Working Paper 620
}

Revised August 2003

\begin{abstract}
Although the role of financial constraints on entrepreneurial choices has received considerable attention, the effects of these constraints on aggregate capital accumulation and wealth inequality are less known. Entrepreneurship is an important determinant of capital accumulation and wealth concentration and, conversely, the distribution of wealth affects entrepreneurial choices in presence of borrowing constraints. We construct a model that matches wealth inequality very well, both for entrepreneurs and non-entrepreneurs, and find that more restrictive borrowing constraints generate less wealth concentration, but also reduce average firm size, aggregate capital and the fraction of entrepreneurs. We also find that voluntary bequests are an important channel that allows some high-ability workers to establish or enlarge an entrepreneurial activity: with accidental bequests only, there would be fewer large firms, fewer entrepreneurs, and less aggregate capital, but also less wealth concentration.
\end{abstract}

*Marco Cagetti: University of Virginia, e-mail: cacio@virginia.edu; Mariacristina De Nardi: University of Minnesota and Federal Reserve Bank of Minneapolis, e-mail: nardi@econ.umn.edu. We gratefully acknowledge funding from NSF. De Nardi also thanks the University of Minnesota Grant-in-Aid for funding. We are grateful to Marco Bassetto, V. V. Chari, Narayana Kocherlakota, Per Krusell, Ellen McGrattan, Victor Ríos-Rull, Emmanuel Saez, Jenni Schoppers, and Kjetil Storesletten for helpful comments. The views of this paper are those of the authors and not necessarily those of the Federal Reserve Bank of Minneapolis, the Federal Reserve System, or the NSF. 


\section{Introduction}

Many empirical studies find that potential and existing entrepreneurs face borrowing constraints, and that the decision to become entrepreneur or expand one's firm depends on own assets, availability of collateral, and receipt of bequests. (See, for example, Evans and Jovanovic [15], Gentry and Hubbard [18], Fazzari, Hubbard and Petersen [17], Hall [21], and Holtz-Eakin et al. [22] and [23].)

Although the role of financial constraints for entrepreneurial choice has received considerable attention, especially from an empirical point of view, there has been so far very little work on how these constraints affect aggregate capital accumulation and wealth inequality through entrepreneurial choices.

In presence of borrowing constraints, the decision to invest, the fraction of entrepreneurs and the size distribution of firms depend on the distribution of assets in the economy. The data show that wealth holdings are extremely concentrated, much more than labor earnings and income (see Díaz-Giménez, Quadrini and Ríos-Rull [14]) and that entrepreneurs are an important force driving wealth concentration and aggregate capital accumulation (Gentry and Hubbard [18] and Quadrini [32]).

In this paper we analyze the role of borrowing constraints as determinants of entrepreneurial decisions (entry, continuation, investment, and saving), and their effects on wealth inequality and aggregate capital accumulation, in a framework that matches the observed wealth inequality very closely. Because of the interaction between borrowing constraints and asset holdings, it is key to perform such an analysis in a model that matches well the extreme concen- 
tration of wealth observed in the data.

We find that more restrictive borrowing constraints generate less inequality in wealth holdings, but also reduces average firm size, the number of people engaging in entrepreneurial activities, and aggregate capital accumulation. Our results also indicate that voluntary bequests are an important channel allowing some high-ability workers to establish or enlarge an entrepreneurial activity and that with accidental bequests only there would be fewer large firms, fewer entrepreneurs, and less aggregate capital, but also less wealth concentration.

These findings are based on a quantitative life-cycle model with altruism across generations and entrepreneurial choice, in an environment in which debt repayment cannot be perfectly enforced. The amount that entrepreneurs can borrow depends, therefore, on their observable characteristics, and the entrepreneurs' assets act as collateral for their debts. Since the implicit rate of return for entrepreneurs is higher than for workers, and consistently with the data, entrepreneurs have a higher saving rate. We calibrate the key parameters of the model, such as entrepreneurial ability and degree of enforcement, to match key moments of the data, and discuss the implications of the model and its components for entrepreneurial choice and wealth inequality. We show that our model with entrepreneurial choice matches very well the the observed distribution of wealth, both for entrepreneurs and non-entrepreneurs.

This paper is related to various works that have studied wealth inequality, entrepreneurial choice, and imperfectly enforceable contracts.

Castañeda, Díaz-Giménez and Ríos-Rull [9] adopt a dynastic model with idiosyncratic shocks and reconstruct a labor income process that matches earnings and wealth dispersion. De Nardi [13] evaluates the importance of bequest 
motives in explaining wealth dispersion in a life cycle model. Neither of these papers model entrepreneurial decisions.

Quadrini [33] shows that modelling entrepreneurship is important to explain the observed concentration of wealth, but does not study the effects of financing constraints. Other papers focus on the effects of different elements on entrepreneurial choice. $\mathrm{Li}$ [29] examines the effects of government credit subsidies, Carranza, Galdòn-Sànchez and Fernandez-Villaverde [8] focus on the impact of capital markets imperfections, Chari, Golosov and Tsyvinski [10] analyze the lock-in-effect of capital gains taxation on business start-ups.

Albuquerque and Hopenhayn [1] characterize optimal contracts and their qualitative implications for firm growth and survival in an environment in which firms face limited liability and repayment of debt cannot be perfectly enforced. Cooley et al. [11], focus on the role of limited contract enforceability in retarding the diffusion of new technologies.

\section{Empirical evidence on entrepreneurship, bor- rowing constraints and wealth}

This section discusses the evidence indicating that entrepreneurs are liquidity constrained and have a higher saving rate than non entrepreneurs. It also highlights the key role of entrepreneurship in generating a skewed wealth distribution.

We use data from the 1989 Survey of Consumer Finances $(\mathrm{SCF}) .^{2}$ Unlike

\footnotetext{
${ }^{2}$ The data for the 1992 and 1995 waves are similar. The results are available from the
} 
other datasets (such as the Panel Study of Income Dynamics and the Health and Retirement Survey), the SCF oversamples rich households and thus provides important advantages. First, it gives a better picture of the concentration of wealth and of the asset holdings of richer households, that include a large share of entrepreneurs. Second, as shown by Curtin et al. [12] and Juster et al. [26], the total wealth implied by the SCF is very close to the total wealth implied by aggregate data (such as the Federal Reserve Board flow of funds accounts); the SCF can thus be used to calibrate aggregates (for instance, the share of entrepreneurial wealth and the percentage of entrepreneurs) in a general equilibrium model such as the one developed in this paper.

We can use different criteria to classify a household as an entrepreneur, based on business asset ownership or on self-declared employment status. To show that the features of the data that we are interested in do not crucially depend on the particular definition of entrepreneurship being used, we adopt here various definitions of entrepreneurship. We will then choose the more appropriate given our purposes, and we will then use to calibrate the model and gauge its validity.

In our model, an entrepreneur must invest his own wealth in the entrepreneurial activity, and his income is primarily the return from this activity. We thus classify as entrepreneurs the households that declare owning a business (or a share of one), and having an active management role in it. ${ }^{3}$ Following Gentry and Hubbard (GH), we further restrict the definition of entrepreneur-

\footnotetext{
authors upon request.

${ }^{3}$ The exact question is: "Do you (or anyone in your family living here) have an active management role in any of these businesses?"
} 
ship to households who own at least $\$ 5,000$ in actively managed businesses, in order to isolate people who have made a significant up-front investment in their business. We call these GH entrepreneurs.

\subsection{Entrepreneurship and borrowing constraints}

Several papers have documented the importance of collateral, the correlation between own assets and external financing, and the relation between wealth and entrepreneurial entry.

Using tax returns, Holz-Eakin et al. [23] study the effects of receiving a bequest on potential and existing entrepreneurs. Interestingly, the households in their sample are rich, consisting only of individuals that received inheritances from substantial estates, and also happened to have high pre-inheritance income (equal to three times the average income for potential entrepreneurs, and to six times average income for existing entrepreneurs). Contrary to the intuition that only the poorer might face borrowing constraints, Holz-Eakin et al. find that even in their sample the receipt of a bequest (and thus an increase in own wealth) increases the probability of starting a business. Even more interestingly, they find that also existing sole-proprietors that receive a bequest are not only more likely to stay in business, but also experience a substantial increase in the enterprise's receipts. Their explanation for this finding is that entrepreneurial businesses are under-capitalized because of liquidity constraints and conclude that "... there is growing evidence that capital market imperfections exert an important influence on business and capital formation.". 
Holz-Eakin et al.'s findings are consistent with those of Fazzari, Hubbard and Peterson [17], and Hall [21], who find that even corporations are constrained in capital markets.

Gentry and Hubbard [18] analyze SCF data and argue that costly external financing (coupled with potentially high returns on those investments) has important implications for the saving, investment, and entry decisions of continuing and potential entrepreneurs.

Evans and Jovanovic [15] estimate a structural model of entrepreneurial choice and find evidence of liquidity constraints. Evans and Leighton [16] find that the probability of switching into self-employment increases with assets. ${ }^{4}$

This evidence thus suggests that entrepreneurs face borrowing constraints and that the possibility of becoming entrepreneurs and level of possible borrowing is related to the level of own wealth.

The need to accumulate assets in the presence of such constraints may also generate high savings rate among entrepreneurs (or household planning to become entrepreneurs). Using different data sets, Gentry and Hubbard [18] and Quadrini's [32] higher saving rates for entrepreneurs than for the rest of the population.

Another fact that is interpreted by many as evidence of borrowing constraints, is that the portfolio of entrepreneurs, even the very rich ones, is very undiversified. Business wealth constitutes a large share of the entrepreneur's total wealth, and even the entrepreneur's own assets are often used as a collateral. In the SCF, the median ratio of business wealth to net worth (for

\footnotetext{
${ }^{4}$ More recently, however, Hurst and Lusardi's [25] findings seem to indicate that this correlation is probably more important for the richest than for the poorer would-be entrepreneurs.
} 


\begin{tabular}{rrrrr}
\hline & $1 \%$ & $5 \%$ & $10 \%$ & $20 \%$ \\
\hline$>50 \%$ & 0.53 & 0.56 & 0.52 & 0.51 \\
$>75 \%$ & 0.19 & 0.27 & 0.27 & 0.28 \\
$>90 \%$ & 0.04 & 0.08 & 0.10 & 0.12 \\
\hline
\end{tabular}

Table 1: Each row reports the fraction of GH entrepreneurs with a business wealth to total net worth ratio higher than the given percentage, among those that are in the top percent (column) of the wealth distribution.

the business owners that have more than $\$ 5000$ in business assets in 1989) is $48 \%$, the third quartile is $77 \%$ and the top decile is $96 \% .^{5}$ Table 1 shows that the share of own wealth invested in one's business is high for all quantiles of the wealth distribution. Approximately half of the net worth is constituted by business wealth both for entrepreneurs in the top and in the bottom of the distribution. The last two rows of table 1 show that the percentage of entrepreneurs who have more than $75 \%$ and $90 \%$ of net worth invested in own assets stays high even for the richest entrepreneurs. Moskowitz and VissingJørgensen [31] also document the poor diversification of the entrepreneurs' portfolio.

Unfortunately, from the SCF it is difficult to isolate exactly business debts, and the characteristics of these debts (conditions, interest charged, whether the amount was limited, and so on). However, the survey asks explicitly about whether some of the debts are explicitly collateralized with own private assets. $33 \%$ of entrepreneurs declare that they currently use own assets as collateral.

\footnotetext{
${ }^{5}$ Some of the results reported in the data sections had already been computed by Gentry and Hubbard [18]. Quadrini [32] also reports similar statistics, but computed using the Panel Study of Income Dynamics.
} 
Within this group, the median amount of collateral is $\$ 36,000$, the top decile is $\$ 300,000$ and the top $5 \%$ is $\$ 570,000$. The median ratio of collateral to business value is $21 \%$, the top decile is $77 \%$ and the top $5 \%$ is $100 \%$. These fractions do not change significantly across quantiles of the wealth distribution, thus suggesting that many business need to put up collateral in order to borrow, regardless of their size. These numbers are just an indication, because they only include the use of personal assets (other than the business itself), and do not indicate the relation between the amount borrowed and the size of the business, nor the amount of borrowing desired by the entrepreneur.

\subsection{Entrepreneurship and the wealth distribution}

Even though entrepreneurs are only a small fraction of the population, they hold a large share of total net worth. GH entrepreneurs, for example, constitute $8.7 \%$ of the population, and hold $39 \%$ of total net worth.

Table 2 shows that entrepreneurs, either identified as by Gentry and Hubbard, or by self-declared self-employment status, constitute a large share of the richest household, and own a large fraction of wealth even among the richest. The second line shows the fraction of wealth held by the corresponding quantile of the richest people that is listed in the first line of the table: the households in the top $1 \%$ of the wealth distribution hold around $30 \%$ of total net worth, and those in the top $5 \%$ hold more than half of the total. The first lines of the other two panels report, respectively, the fraction of GH entrepreneurs, or the fraction of self-employed in the corresponding wealth quantile. The second line of each panel displays, respectively, the fraction of total wealth held by en- 


\begin{tabular}{lcccc}
\hline Top \% & 1 & 5 & 10 & 20 \\
\hline $\begin{array}{l}\text { Whole population } \\
\text { percentage of total net worth held }\end{array}$ & 30 & 54 & 67 & 81 \\
\hline $\begin{array}{l}\text { GH entrepreneurs } \\
\text { percentage of households in a given percentile }\end{array}$ & 65 & 52 & 42 & 30 \\
percentage of net worth held in a given percentile & 69 & 60 & 55 & 49 \\
\hline $\begin{array}{l}\text { Self-employed } \\
\text { percentage of households in a given percentile }\end{array}$ & 62 & 47 & 38 & 26 \\
percentage of net worth held in a given percentile & 69 & 57 & 52 & 46 \\
\hline
\end{tabular}

Table 2: First and second row: percentage of total net worth held by top $\%$ of the wealth distribution. Two panels: percentage of entrepreneurs or selfemployed among the household in the top $\%$ of the wealth distribution, and share of wealth held by entrepreneurs or self-employed in those quantiles.

trepreneurs or self-employed as a fraction of the total wealth in a given wealth quantile. More than $60 \%$ of those in the top $1 \%$, and almost one half of those in the top $5 \%$ are entrepreneurs or self-employed, and they hold respectively $69 \%$ and $60 \%$ of the wealth held by household in those quantiles. The table also shows that the corresponding statistics for the self-employed are very close to the ones for the entrepreneurs.

\subsection{More about entrepreneurs}

Table 3 uses the SCF to compares various definitions of entrepreneurship. The percentage of households whose head declares himself self-employed is around $10 \%$, similar to the percentage of entrepreneurs. However, only around two thirds of the self employed have business assets, and only slightly more than a half of them have more than $\$ 5,000$ invested in a business. 


\begin{tabular}{lcc}
\hline & Percentage in population & Share of total wealth \\
\hline Entrepreneurs & 11.5 & 41.6 \\
GH entrepreneurs & 8.7 & 38.8 \\
Self employed & 11.1 & 39.0 \\
\hline \multicolumn{2}{c}{ Percentage in population } \\
\hline Self employed who are entrepreneurs & 67.5 \\
Self employed who are GH entrepreneurs & 52.7 \\
\hline
\end{tabular}

Table 3: Top panel: percentage of various definitions of entrepreneurs in the population and corresponding share of the total wealth held. Bottom panel: fraction of self-employed that are entrepreneurs.

There is thus a difference between being self employed and owning business assets. Some self-employed households do not invest any of their (non-human) wealth in their activity, or invest only a very small amount. The difference between those two groups is highest in the lower quantiles of the wealth distribution, where the self-employed tend to be poorer than the entrepreneurs, and many of them have no business assets. For the higher quantiles, however, the two groups are almost the same. For instance, most (from $85 \%$ to $90 \%$, depending on the year) of the self-employed who are in the top $5 \%$ of the overall wealth distribution are also entrepreneurs according to the GH definition. Therefore, if one is mainly interested in the total wealth held by those groups, or in the right tail of the wealth distribution, there is little difference in using either definition. Since, for us, a key aspect of entrepreneurship is ownership of and investment in business assets, we use the GH definition for our computations.

As for the distribution by type of business, roughly a half of the businesses are sole proprietorships, a quarter partnership, and a quarter are incorporated. 
While a few of those that have a management role in a corporation should be classified as managers rather than entrepreneurs who invest their own wealth, the previous section shows that most entrepreneurs have a significant share of own wealth invested in their business. In fact, the ratio of business assets to total net worth, and the fraction of entrepreneurs who have collateralized loans is very similar across these different groups, as well as across different types of business activities.

\section{The model}

\subsection{Demographics}

We adopt a life-cycle model with intergenerational altruism. To make the results quantitatively interesting, we need short time periods. To make the model computationally manageable, we have to keep the number of stages of life small. To reconcile these two necessities, we adopt a modeling device introduced by Yaari [38] and Blanchard [6], and generalized by Gertler [19] to a life-cycle setting.

Households go through two stages of life, young and old age. A young person faces a constant probability of aging during each period $\left(1-\pi_{y}\right)$ and an old person faces a constant probability of dying during each period (1 $\pi_{o}$ ). When an old person dies, his offspring enters the model, carrying the assets bequeathed to him by the parent. Appropriately parameterized, this framework generates households for which the average length of the working period and the retirement period is realistic. Our model period is one year 
long.

There is a continuum of households of measure 1. The households are subject to idiosyncratic shocks but there is no aggregate uncertainty, as in Bewley [5].

\section{$3.2 \quad$ Preferences}

The household's utility from consumption is given by: $\frac{c^{1-\sigma}}{1-\sigma}$. The households discount the future at rate $\beta$ and, in addition, they discount the utility of their offspring at rate $\eta$.

To study the role of bequests, our model nests life-cycle and fully altruistic households as two extreme cases. In the purely life-cycle version of the model individuals put no weight on the utility of their descendants $(\eta=0)$. In the perfectly altruistic version individuals care about their descendants as much as themselves $(\eta=1)$. We assume exogenous labor supply.

\subsection{Technology}

Many firms are not controlled by a single entrepreneur and are not likely to face the same financing restrictions that we stress in our model. Therefore, as in Quadrini [33], we model two sectors of production: one populated by the entrepreneurs, and one by "non-entrepreneurial" firms. The non-entrepreneurial sector is represented by a standard Cobb-Douglas production function.

$$
F\left(K_{c}, L_{c}\right)=A K_{c}^{\alpha} L_{c}^{1-\alpha}
$$


where $K_{c}$ and $L_{c}$ are the total capital and labor inputs in the non-entrepreneurial sector and $A$ is a constant. In both sectors, capital depreciates at a rate $\delta$.

Each person possesses two different types of ability, which we take to be exogenous, stochastic, positively correlated over time, and uncorrelated with each other. Entrepreneurial ability $(\theta)$ is the capacity to invest capital more or less productively. Working ability $(y)$ is the capacity to produce income out of labor.

Workers can save (but not borrow) at a riskless, constant, rate of return.

Entrepreneurs can borrow and invest capital in a technology whose return depends on their own entrepreneurial ability: those with higher ability levels have higher average and marginal returns from capital. When the entrepreneur invests $k$, the production net of depreciation is given by $(1-\delta) k+\theta k^{\nu}$, with $0<\nu<1$.

Entrepreneurs thus face decreasing returns from investment, as their managerial skills become gradually stretched over larger and larger projects. Hence, while entrepreneurial ability is exogenously given, the entrepreneurial rate of return from investing in capital is endogenous and is a function of the size of the project that the entrepreneur implements.

Note that there is no within-period uncertainty regarding the returns of the entrepreneurial project. $\theta$ is observable and known by all at the beginning of the period. We ignore therefore problems arising both from partial observability and costly state verification, and from diversification of entrepreneurial risk. The simplification is adopted to focus only on the effect of the borrowing constraint.

We assume that the entrepreneurs work on their own project without hiring 
labor and that all of the workers are hired by the non-entrepreneurial sector.

In equilibrium the prices are given by the marginal products of each factor of production and the rate of return from investing in capital in the nonentrepreneurial sector must equate the risk free rate that equates savings and investment.

\subsection{Credit market constraints}

As in Albuquerque and Hopenhayn [1] and Kehoe and Levine [27], the borrowing constraints are endogenously determined in equilibrium, and stem from the assumptions that contracts are imperfectly enforceable.

Imperfect enforceability of contracts means that the creditors will not be able to force the debtors to fully repay their debts as promised, but that the debtors fully repay only if it is in their own interest to do so. Since both parties are aware of this feature and act rationally, the lender will lend to a given borrower only an amount (possibly zero) that will be in the debtor's interest to repay as promised.

In particular, we assume that the entrepreneurs who borrow can either invest the money and repay their debt at the end of the period, or can run away without investing it, and be workers for one period. In the latter case, they retain a fraction $f$ of their working capital $k$ (which includes own assets and borrowed money) and their creditors seize the rest.

In the absence of market imperfections, the optimal level of capital is only related to technological parameters, and does not depend on initial assets. In our framework, instead, the higher the amount of own wealth invested in the 
business, the larger is the amount that the creditor is able to recover, and the larger is thus the sum that she is willing to lend to the entrepreneur. Hence, the entrepreneur's assets act as collateral.

As a result, not all potentially profitable projects receive appropriate funding. Households with little wealth can borrow little, even if they have high ability as entrepreneurs. Since the entrepreneur foregoes his potential earnings as a worker, he will choose to become an entrepreneur only if the size of the firm that he can start is big enough, that is, if he is rich enough to be able to borrow and invest a suitable amount of money in his firm.

\subsection{Households}

At the beginning of each period, before taking any economic decisions, the current ability levels are known with certainty, while next period's ones are uncertain.

Each young individual starts the period with assets $a$, entrepreneurial ability $\theta$, and worker ability $y$, and chooses whether to be an entrepreneur or a worker during the current period.

An old entrepreneur can decide to keep the activity going or retire, while a retiree cannot start a new entrepreneurial activity. We allow entrepreneurs to remain active when old to capture the fact that, while most workers retire before age 65 , entrepreneurs often continue their activity until much later. 


\subsubsection{The young's problem}

The young's state variables are his current assets $a$, earnings ability $y$, and entrepreneurial ability $\theta$. His value function is:

$$
V(a, y, \theta)=\max \left\{V_{e}(a, y, \theta), V_{w}(a, y, \theta)\right\}
$$

$V_{e}(a, y, \theta)$ is the value function of a young individual that manages an entrepreneurial activity during the current period. In order to invest $k$ the young entrepreneur borrows $(k-a)$ from a financial intermediary at the interest rate $r$, which is the risk-free interest rate at which people can borrow and lend in this economy. Consumption $c$ is enjoyed at the end of the period.

$$
\begin{gathered}
V_{e}(a, y, \theta)=\max _{c, k, a^{\prime}}\left\{u(c)+\beta \pi_{y} E V\left(a^{\prime}, y^{\prime}, \theta^{\prime}\right)+\beta\left(1-\pi_{y}\right) E W\left(a^{\prime}, \theta^{\prime}\right)\right\} \\
a^{\prime}=(1-\delta) k+\theta k^{\nu}-(1+r)(k-a)-c \\
V_{e}(a, y, \theta) \geq V_{w}(f \cdot k, y, \theta) \\
a \geq 0 \\
k \geq 0
\end{gathered}
$$

The expected value of the value function is taken with respect to $\left(y^{\prime}, \theta^{\prime}\right)$, conditional on $(y, \theta) . F\left(y^{\prime}, \theta^{\prime} \mid y, \theta\right)$ is a first order Markov process. $W\left(a^{\prime}, \theta^{\prime}\right)$ is the value function of the old entrepreneur at the beginning of the period, before deciding whether he wants to stay in business or retire.

$V_{w}(a, y, \theta)$ is the value function if the young that chooses to be a worker 
during the current period. We have:

$$
V_{w}(a, y, \theta)=\max _{c, a^{\prime}}\left\{u(c)+\beta \pi_{y} E V\left(a^{\prime}, y^{\prime}, \theta^{\prime}\right)+\beta\left(1-\pi_{y}\right) W_{r}\left(a^{\prime}\right)\right\}
$$

subject to eq. (6) and

$$
a^{\prime}=(1+r) a+w y-c
$$

Where $w$ is the wage. When the worker becomes old, he is retired, and $W_{r}\left(a^{\prime}\right)$ is the corresponding value function.

\subsubsection{The old's problem}

The old entrepreneur can choose to continue the entrepreneurial activity or retire. The old's person state variables are therefore his current assets $a$, entrepreneurial ability $\theta$, and whether he was a retiree or an entrepreneur during the previous period.

The value function of an old entrepreneur is:

$$
W(a, \theta)=\max \left\{W_{e}(a, \theta), W_{r}(a)\right\}
$$

$W_{e}(a, \theta)$ is the value function for the old entrepreneur that stays in business. $W_{r}(a)$ is the value function of the old, retired person. $\eta$ is the weight on the utility of the descendants: if $\eta=0$, the household behaves as pure life-cycle, if $\eta=1$ the household behaves as a dynasty.

$$
W_{e}(a, \theta)=\max _{c, k, a^{\prime}}\left\{u(c)+\beta \pi_{o} E W\left(a^{\prime}, \theta^{\prime}\right)+\eta \beta\left(1-\pi_{o}\right) E V\left(a^{\prime}, y^{\prime}, \theta^{\prime}\right)\right\}
$$


subject to eq. (4), eq. (7) and

$$
W_{e}(a, \theta) \geq W_{r}(f \cdot k)
$$

The child of an entrepreneur is born with ability level $\left(\theta^{\prime}, y^{\prime}\right)$. The expected value of the child's value function with respect to $y^{\prime}$ is computed using the invariant distribution of $y$, while the one with respect to $\theta^{\prime}$ is conditional on the parent's $\theta$ and evolves according to the same Markov process that each person faces for $\theta$ while alive. This is justified by the assumption that the child of an entrepreneur inherits the parent's firm.

A retired person (who is not an entrepreneur) receives pensions and social security payments $(p)$ and consumes his assets. His value function is:

$$
W_{r}(a)=\max _{c, a^{\prime}}\left\{u(c)+\beta \pi_{o} E W_{r}\left(a^{\prime}\right)+\eta \beta\left(1-\pi_{o}\right) E V\left(a^{\prime}, y^{\prime}, \theta^{\prime}\right)\right\}
$$

subject to eq. (6) and

$$
a^{\prime}=(1+r) a+p-c
$$

\subsection{Equilibrium}

Let $x=(a, y, \theta, s)$ be the state vector for our economy, where $s$ distinguishes young workers, young entrepreneurs, old entrepreneurs, and old retired. From the decision rules that solve the maximization problem and the exogenous Markov process for income and entrepreneurial ability, we can derive a transition function $M(x, \cdot)$, which provides the probability distribution of $x^{\prime}$ (the state next period) conditional on $x$. 
A stationary equilibrium is given by

a risk free interest rate $r$ and wage rate $w$

allocations $c(x), a(x)$, and $k(x)$

and a constant distribution of people over the state variables $x: m^{*}(x)$

such that, given $r, w$ :

- the functions $c, a$ and $k$ solve the maximization problem described above.

- the capital and labor markets clear. The total labor supplied by the workers equal the total labor employed in the non-entrepreneurial sector. The total savings in the economy equal the sum of the total capital employed in the non-entrepreneurial and in the entrepreneurial sectors.

- the wage and interest rate are given by the marginal products of each factor of production and the rate of return from investing in capital in the non-entrepreneurial sector must equate the risk free rate that equates savings and investment.

- $m^{*}$ is the invariant distribution for the economy.

\subsection{Calibration}

Table 4 lists the parameters of the model. The first panel of table 4 shows the set of parameters that we take from other studies and do not use to match moments of the data.

We take the coefficient of relative risk aversion to be 1.5, a value close to those estimated, among others, by Attanasio et al. [2]. As standard in 


\begin{tabular}{|c|c|c|c|}
\hline Fixed Parameter & \multicolumn{2}{|l|}{ Value } & Source(s) \\
\hline$\sigma$ & 1.5 & & Attanasio et al. [2] \\
\hline$\delta$ & .06 & & Stokey and Rebelo [34] \\
\hline$\alpha$ & .33 & & Gollin [20] \\
\hline$A$ & 1 & & Normalization \\
\hline$\pi_{y}$ & .98 & & see text \\
\hline$\pi_{o}$ & .91 & & see text \\
\hline$P_{y}$ & see text & & Huggett [24], Lillard et al. [30] \\
\hline$p$ & $40 \%$ average yearly & income & Kotlikoff et al. [28] \\
\hline$\eta$ & 1.0 & & Perfect Altruism \\
\hline & Calibrated & & \\
\hline & Parameter & Value & \\
\hline & $\beta$ & .852 & \\
\hline & $\theta$ & {$[0,0.55]$} & \\
\hline & $P_{\theta}$ & see text & \\
\hline & $\nu$ & .88 & \\
\hline & $f$ & $75 \%$ & \\
\hline
\end{tabular}

Table 4: Parameters of the model. 
the business cycle literature, we choose a depreciation rate $\delta$ of $6 \%$. The share of income that goes to capital in the non-entrepreneurial sector is .33, and the scaling factor $A$ is normalized to 1 . The probability of aging and of death are such that the average length of the working life is 45 years, and the average length of the retirement period is 11 years. The logarithm of the income $y$ process for working people is assumed to follow an $\mathrm{AR}(1)$. We take its persistence to be .95 , as estimated, for instance, by Storesletten et al. [36]. The variance is chosen to match the Gini coefficient for earnings of .38 , the average found in the PSID. We assume that the income and the entrepreneurial ability processes evolve independently; the exact values for the income and ability processes are described in appendix A. The social security replacement rate is $40 \%$ of average income, net of taxes (see Kotlikoff et al. [28]). In the baseline case we set $\eta=1$ (perfect altruism) and then study the no-altruism case.

The second panel of table 4 lists the remaining parameters of the model: $\beta, \theta, P_{\theta}, \nu, f$ and their corresponding values in the baseline calibration. We consider only two values of entrepreneurial ability: zero (no entrepreneurial ability) and a positive number. This implies that $P_{\theta}$ is a two by two matrix. Since its rows have to sum to one, this gives us two parameters to calibrate, corresponding to the persistence of each of the two ability states. We also have to choose values for $\nu$, the degree of decreasing returns to scale to entrepreneurial ability, and $f$, the fraction of working capital the entrepreneur can keep in case he defaults. This gives us a total of six parameters to calibrate to the data. ${ }^{6}$

\footnotetext{
${ }^{6}$ Note that we do not impose exogenous minimum firm size or investment level, nor
} 
We use these six parameters to pin down the following moments generated by the model: the capital to GDP ratio, the fraction of entrepreneurs in the population, the fraction of entrepreneurs exiting entrepreneurship during each period, the fraction of workers becoming entrepreneurs during each period, the ratio of median net worth of entrepreneurs to that of workers, and the fraction of people with zero wealth.

Given the features matched in the calibration, we analyze how well the model matches the overall distribution of wealth and the distributions of wealth for entrepreneurs and workers. We then study the role of borrowing constraints and voluntary bequests.

\subsection{Results}

The first row in table 1 displays the aggregate capital-output ratio and several statistics on the wealth distribution in the United States. The notion of capital that we use includes residential structures, plant, equipment, land and consumer durables, and implies a capital output ratio of about 3 for the period 1959-1992 (Auerbach and Kotlikoff [3]). The ratio of average wealth to average income is also about 3 . The data pertaining to the distribution of wealth come from the $1989 \mathrm{SCF}$ (the waves for other years are similar).

In the other rows of the table we report the corresponding statistics generated by the simulations of various versions of our model economy.

startup costs. We experimented adding a fixed startup cost and a minimum firm size (both of the order of $\$ 5,000-20,000)$, but doing so had no significant impact on our numerical results. 


\begin{tabular}{lccccccc}
\hline $\begin{array}{c}\text { Capital } \\
\text { output } \\
\text { ratio }\end{array}$ & $\begin{array}{c}\text { Wealth } \\
\text { Gini }\end{array}$ & $\begin{array}{c}\text { Perc. } \\
\text { entr. }\end{array}$ & $1 \%$ & $5 \%$ & $20 \%$ & $40 \%$ & $\begin{array}{c}\text { Perc. } \\
\text { at zero }\end{array}$ \\
\hline $\begin{array}{l}\text { U.S. data } \\
3.0\end{array}$ & .78 & $8.7 \%$ & 30 & 54 & 81 & 94 & $16 \%$ \\
\hline $\begin{array}{l}\text { Baseline } \\
3.0\end{array}$ & .53 & $0.0 \%$ & 4 & 18 & 53 & 94 & $7 \%$ \\
\hline $\begin{array}{l}\text { Baseline with entrepreneurs } \\
3.0\end{array} \quad .83$ & $8.7 \%$ & 31 & 62 & 85 & 95 & $16 \%$ \\
\hline
\end{tabular}

Table 5: U.S. calibration.

\subsubsection{The model without entrepreneurs}

The second row of table 1 refers to the model economy without entrepreneurs. In this run, we assign zero entrepreneurial ability to everyone, and change the household's discount factor to match the same capital to GDP ratio. All other parameters, including the general equilibrium prices, are the same as in the benchmark economy.

These results thus refer to a model economy with labor earnings risk and a simplified life-cycle structure. As we can see from the table, this model economy produces a distribution of wealth that is much less concentrated than in the data and that, in particular, does not explain the emergence of the large estates that characterize the upper tail of the distribution of wealth. Figure 1 compares the data on the distribution of wealth (SCF, 1989 in thousands of dollars) with the one implied by the model without entrepreneurial choice. While the data on wealth display a fat tail, in the model without entrepreneurial choice all households hold less than $\$ 1.1$ million dollars. 


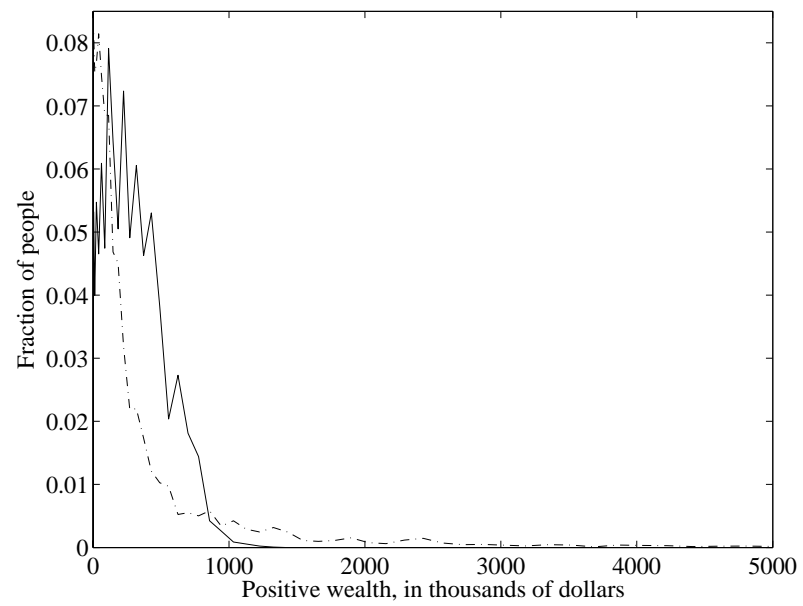

Figure 1: Distribution of wealth for the whole population, dash-dot line: data; solid line: model without entrepreneurs.

\subsubsection{The model with entrepreneurs}

The third row of table 1 refers to the benchmark economy with entrepreneurs. In our baseline simulation the equilibrium interest rate $r$ is $6.3 \%$, the share of total wealth held by entrepreneurs is $34 \%$, compared with $39 \%$ in the data, and the degree of decreasing returns to scale to the entrepreneurial technology is .88, which is a value consistent with the ones estimated by Burnside, Eichenbaum and Rebelo [7] and Basu and Fernald [4]. The resulting fraction of total capital invested by the entrepreneurial sector is $43 \%$, a value very close to the $40 \%$ estimated by Quadrini [33].

This parameterization matches the distribution of wealth very well (see figure 2), both for the overall population, and for that of the entrepreneurs. Figure 3 compares the wealth distributions generated by the model for entrepreneurs and workers. Figure 4 shows the wealth distribution for the subpopulation of entrepreneurs, for the model and the data. These pictures reveal 


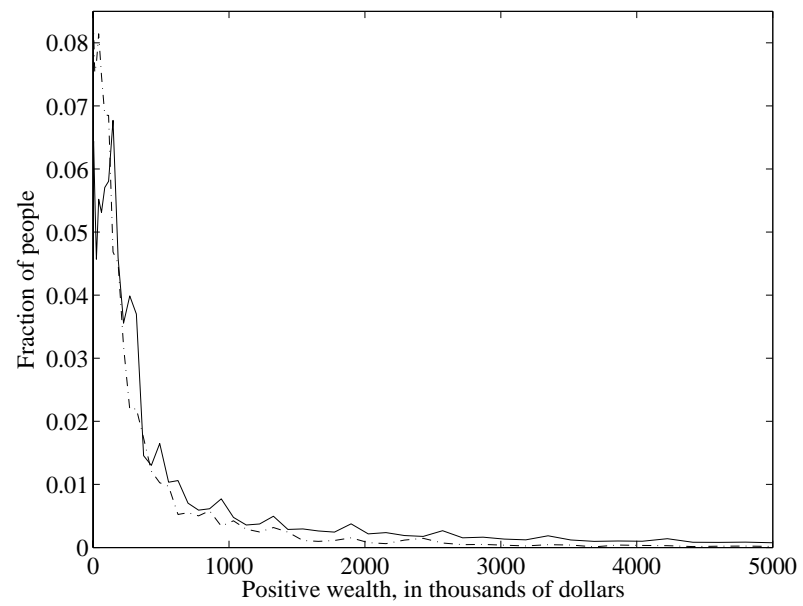

Figure 2: Distribution of wealth for the whole population, dash-dot line: data; solid line: baseline model with entrepreneurs.

two important features of the baseline model. First, and consistently with the data, the distribution of wealth for the population of entrepreneurs displays a much fatter tail than the one for workers. Second, contrary to the model without entrepreneurial choice, the baseline model generates distributions of wealth for both entrepreneurs and non entrepreneurs with a significant mass of people that own more than 1.1 million dollars. In the model, the non-entrepreneurs in the right tail of the wealth distribution are former entrepreneurs, or descendant of entrepreneurs who have not continued the business of the parents.

In order to understand entrepreneurial behavior, figure 5 displays the saving rate $^{7}$ for people that have the highest ability level as workers during the current period. The solid line refers to the people that get the high entrepreneurial ability level during the current period, while the dash-dot line refers to those

\footnotetext{
${ }^{7}$ The savings rate in the graph is defined as assets in a given period minus assets in the previous period, divided by total income during the period.
} 


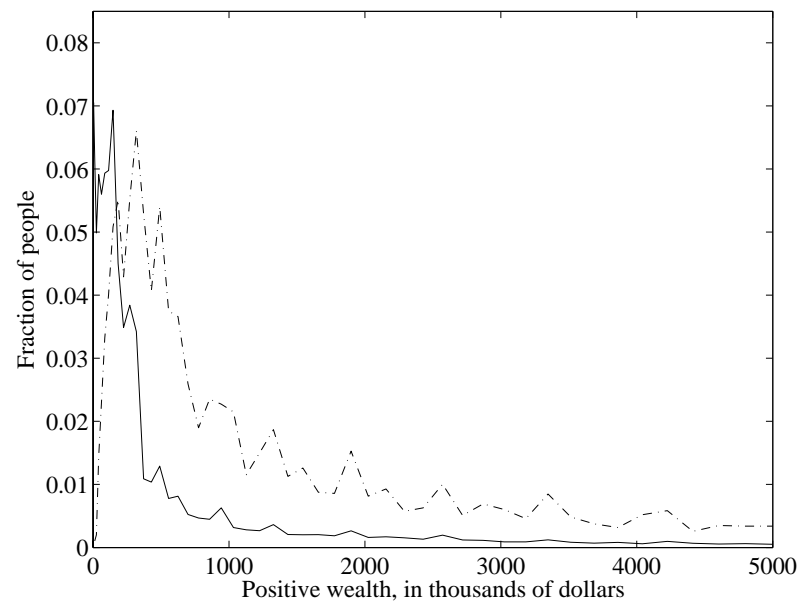

Figure 3: Distribution of wealth in the baseline model with entrepreneurs. Solid line: workers; dash-dot line: entrepreneurs.

that get the low entrepreneurial ability draw. Given the same asset level (and potential earnings as workers), the people with high entrepreneurial ability have a much higher saving rate.

Those with low entrepreneurial ability (and are thus workers) exhibit bufferstock saving behavior: if their assets are low they save because they are experiencing a high ability level as workers and want to build up their buffer-stock. If their assets are high enough, they dissave and the rate of dissaving is larger, the richer they are. In this simulation, the asset level at which the saving rate goes from positive to negative is below one million dollars.

The people with high entrepreneurial ability, as explained in section 3.4, become entrepreneurs only if their wealth is above a certain level, denoted in the graph by a vertical line. The saving rate of those with high entrepreneurial ability that do not own enough assets to become entrepreneurs is higher than the one for the workers because ability is persistent, and the workers with 


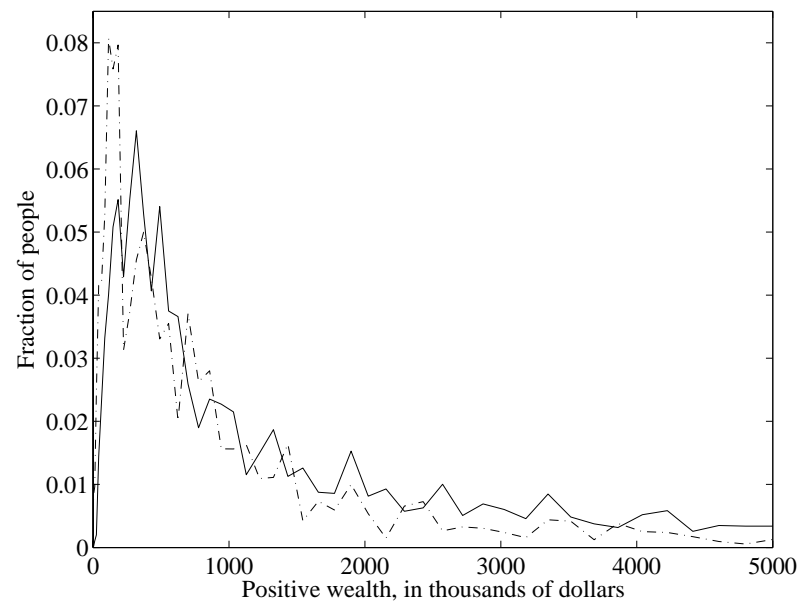

Figure 4: Distribution of the entrepreneurs' wealth, dash-dot line: data; solid line: baseline model.

high entrepreneurial ability save to have a chance to start a business in the future. In this region, the distance between the solid line and the dash-dot line is solely due to the higher implicit rate of return from saving that one could obtain becoming an entrepreneur in the future: all households become workers in this range and earn the same income, but the desire to become entrepreneurs generates higher savings rate for those who have such ability.

The saving rate of those with high entrepreneurial ability and enough assets to become entrepreneurs is positive and considerably higher than that for workers. The return on the entrepreneurial activity is high, and the entrepreneur would like to increase the size of the firm by borrowing capital. However, the borrowing constraint limits the size of the firm. In order to expand the business, the entrepreneur must in part self finance the increase in capital. The combination of higher returns from the business together with the budget constraint thus generates a very high saving rate for entrepreneurs. 


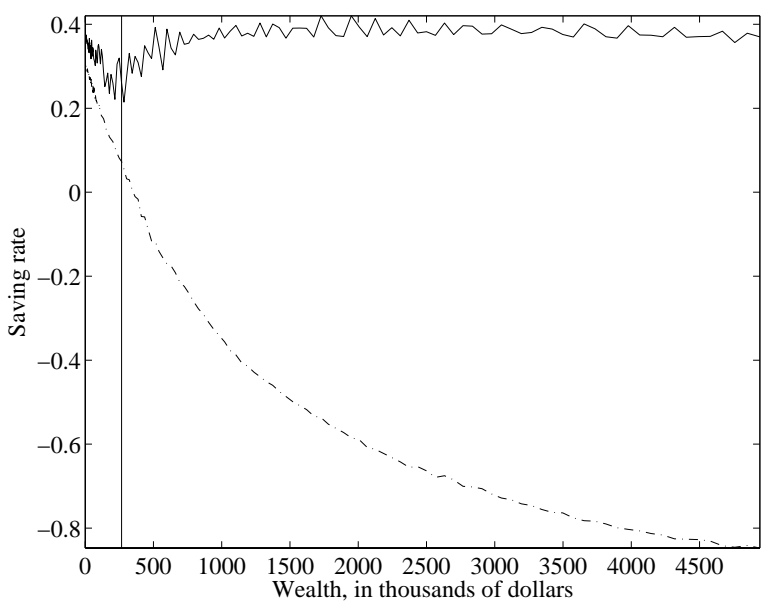

Figure 5: Saving rate for highest ability workers. Solid line: with high entrepreneurial ability; dash-dot line: with no entrepreneurial ability. Vertical line: asset level at which high-entrepreneurial-ability individuals enter entrepreneurship.

As the firm expands, the returns decrease. Therefore, also the savings rate will eventually decrease (we truncate the axis of the graph for easier readability).

With only one positive level of entrepreneurial ability (as we assume in our calibration) and in the absence of borrowing constraints, there would be only one optimal firm size. Figure 6 shows how in our framework the presence of borrowing constraints can generate a large amount of heterogeneity in the firm size distribution. The distribution generated by the model exhibits high dispersion and a fat tail; the tail is generated by the entrepreneurs who have remained in business for a long period (and have possibly inherited the firm from the parents) and have had thus time to save and increase the size of their firm. 


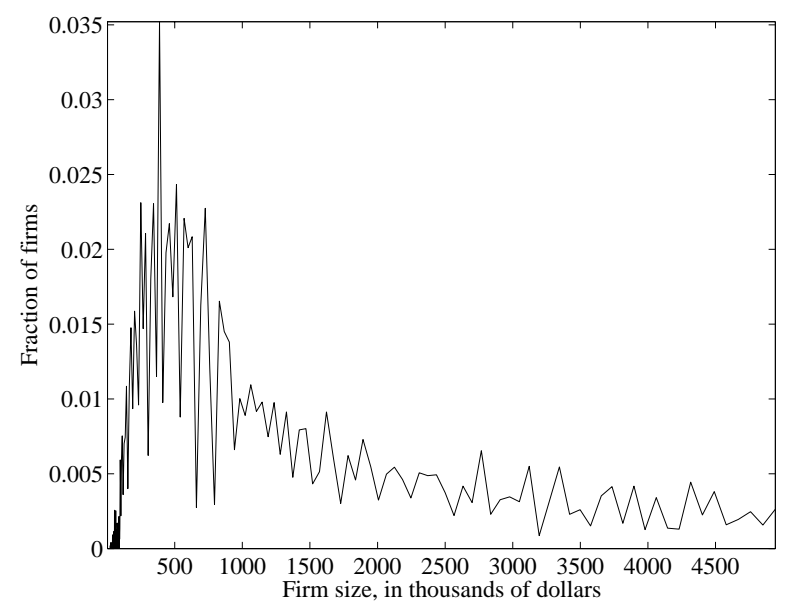

Figure 6: Firm size distribution, baseline model with entrepreneurs.

\subsubsection{The borrowing constraints}

In this section, we examine the effect of changing tightness of the borrowing constraints. To make the constraint more stringent, we increase $f$, the fraction of working capital that cannot be seized by creditors, from .75 to .85 . The less the creditors can get back, the less they lend to the entrepreneur. This increase in $f$ could be interpreted as a less efficient the enforcement of the property rights by the courts, or as more lenient bankruptcy laws.

Figure 7 shows the maximum amount of investment (including own assets and borrowed funds) for a young entrepreneur that has the highest ability level as a worker, as a function of his own assets. The solid line refers to the baseline model, while the dash-dot line refers to the model with more restrictive borrowing constraints (and non recalibrated $\beta$ ). In both economies the entrepreneurs with little assets cannot borrow. The amount of collateral necessary to borrow a positive amount in the two economies coincides at low 


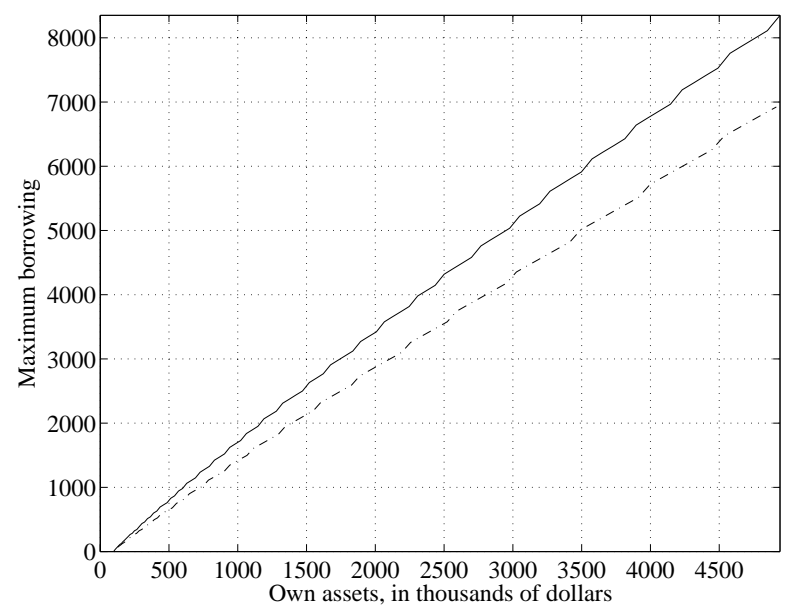

Figure 7: Maximum borrowing, solid line:baseline; dash-dot line:more restrictive borrowing constraints.

levels of assets. The entrepreneur with lowest ability level as a worker must own at least $\$ 16,000$ in order to borrow some funds; this amount increases to $\$ 266,000$ for the entrepreneur with highest ability level as a worker. This happens because a more able worker is better off in case of default, therefore he has to provide more collateral. The key difference in the two economies is that richer entrepreneurs can borrow and invest less in the economy with more restrictive borrowing constraints. For this reason they need more initial assets to implement a project of a given size and it takes them longer to become rich and own and run a large firm. If the entrepreneur is rich enough, he is unconstrained.

The third line of table 6 reports the effects of more restrictive borrowing constraints. The capital to GDP ratio drops drastically, from 3.0 to 2.6, and the fraction of entrepreneurs falls from $8.7 \%$ to $7.9 \%$ as fewer high-ability individuals can now borrow and start a firm. The decrease in the fraction 


\begin{tabular}{|c|c|c|c|c|c|c|c|}
\hline \multirow{2}{*}{$\begin{array}{l}\text { Capital } \\
\text { output } \\
\text { ratio }\end{array}$} & \multirow[b]{2}{*}{$\begin{array}{c}\text { Wealth } \\
\text { Gini }\end{array}$} & \multicolumn{6}{|c|}{ Percentage wealth in the top } \\
\hline & & $\begin{array}{l}\text { Perc. } \\
\text { entr. }\end{array}$ & $1 \%$ & $5 \%$ & $20 \%$ & $40 \%$ & $\begin{array}{l}\text { Perc. } \\
\text { at zero }\end{array}$ \\
\hline \multicolumn{8}{|c|}{ U.S. data } \\
\hline 3.0 & .78 & $8.7 \%$ & 30 & 54 & 81 & 94 & $16 \%$ \\
\hline \multicolumn{8}{|c|}{ Baseline with entrepreneurs } \\
\hline 3.0 & .83 & $8.7 \%$ & 31 & 62 & 85 & 95 & $16 \%$ \\
\hline \multicolumn{8}{|c|}{ More stringent borrowing constraints: $f=0.85$} \\
\hline 2.6 & .78 & $7.9 \%$ & 26 & 53 & 79 & 93 & $15 \%$ \\
\hline \multicolumn{8}{|c|}{ No altruism: $\eta=0$, only involuntary bequests } \\
\hline 2.6 & .76 & $8.5 \%$ & 23 & 49 & 77 & 92 & $15 \%$ \\
\hline \multicolumn{8}{|c|}{$\eta=0$, recalibrated $\beta$} \\
\hline 3.0 & .80 & $9.1 \%$ & 26 & 57 & 83 & 94 & $16 \%$ \\
\hline
\end{tabular}

Table 6: Borrowing constraints and bequests.

of entrepreneurs happens despite an increase of the equilibrium interest rate from $6.3 \%$ to $7.6 \%$, which makes it easier (and faster) for savers with high entrepreneurial ability to accumulate enough capital to start a business.

An increase in the tightness of the borrowing constraint, as seen in figure 7, forces entrepreneurs, and in particular rich ones, to borrow less and run smaller firms. They make less total profits and save less, and, as a result, they are poorer. The distribution of wealth becomes less concentrated, for instance the share of total net worth held by the richest $1 \%$ decreases from $30 \%$ in the baseline calibration to $26 \%$, and the share of total net worth held by entrepreneurs decreases from $34 \%$ to $30 \%$.

Hence, as the collateral requirements rise, wealth inequality falls, but this comes at the expense of lower capital accumulation and output. 


\subsubsection{Bequests}

In the baseline economy households are altruistic towards their children, therefore the total amount of bequests includes both voluntary and accidental bequests due to life-span risk. We use our model to study what happens to entrepreneurial choice and to wealth inequality when households do not care about their descendants and all bequests are accidental.

The fifth line of table 6 displays how the aggregates change when we set to zero the degree of intergenerational altruism. The absence of the voluntary bequest motive reduces the incentives to accumulate capital and run larger and larger firms. On the one hand, younger people are bequeathed less wealth, and in the presence of borrowing constraints, this means that young potential entrepreneurs have less resources to start and increase their businesses. On the other hand, the equilibrium interest rate increases to $8.7 \%$, thus allowing more high-ability individuals to use the increased proceedings from their earnings to start a business activity. The net effect on the total fraction of entrepreneurs is a small decrease from $8.7 \%$ to $8.5 \%$.

The effects on aggregate capital accumulation are large: in absence of a voluntary bequest motive to save, the total capital of the economy would decrease from 3.0 to 2.6. The concentration of wealth would also drop substantially: the Gini coefficient of inequality would go from .83 to .78 and the fraction of wealth held by the richest $1 \%$ from $31 \%$ to $23 \%$. As shown also in other papers, such as De Nardi [13] and Castañeda et al. [9], voluntary bequests are fundamental to explain the concentration of wealth.

In this model economy, voluntary bequests provide an additional reason to 
save to rich entrepreneurs and also generates the intergenerational transmission of large fortunes (and firms) across generations.

To better understand the role of voluntary bequests, we run another experiment, in which we increase the discount factor $\beta$ (last line of the table) to match a capital-output ratio of 3.0. The fraction of entrepreneurs increases compared to the baseline model, from $8.7 \%$ to $9.1 \%$. This effect is due to an increase in the general equilibrium interest rate, which has the same effect we have discussed above, and to the increase in the household's discount factor. In this calibration, households have no bequest motive, but are more patient. This implies that the younger households accumulate more wealth than in the baseline model, while the old decumulate faster, and thus keep less wealth, because of the lack of altruism. More people of working age become entrepreneurs, and the old have less incentives to continue and expand the entrepreneurial activity, and pass to their offspring less wealth, and smaller firms. This reduces the number and the size of large firms. For these reasons, the wealth concentration generated by this experiment is lower than the one in the benchmark economy; for instance the share of total net worth held by the richest $1 \%$ drops to $26 \%$, down from $31 \%$.

\section{Conclusions}

We developed and solved numerically a model of wealth accumulation and bequests in which entrepreneurs face an endogenous borrowing constraint that limits the amount that they can borrow. The entrepreneur's wealth acts as collateral, so that the richer the entrepreneur, the higher the amount that 
he can borrow. We show that this setup can generate a wealth distribution that matches the one observed in the data, with a small number of very rich households, many of whom are entrepreneurs. Because of the relation between wealth and borrowing limits, entrepreneurs, although richer, have higher saving rate than workers. We also show that the tightness of borrowing constraints and voluntary bequests are key forces in determining the number of entrepreneurs and the size of their firms, as well as the overall wealth concentration in the population.

These results have implications for policy analysis, such as subsidized loans to entrepreneurs and estate taxes. Subsidized loans would make it cheaper for the entrepreneurs to borrow, but also change their incentives to default, making the effects of this policy a priori ambiguous. Taxing bequests may decrease inequality, while at the same time reduce the amount of entrepreneurial wealth that could be used as a collateral, and thus reduce both the number of entrepreneurs, and the total capital of the economy. We leave these issues for future research.

\section{References}

[1] Rui Albuquerque and Hugo A. Hopenhayn. Optimal dynamic lending contracts with imperfect enforceability. Review of Economic Studies, 2003. Forthcoming.

[2] Orazio P. Attanasio, James Banks, Costas Meghir, and Guglielmo Weber. Humps and bumps in lifetime consumption. Journal of Business and Economic Statistics, 17(1):22-35, January 1999. 
[3] Alan J. Auerbach and Laurence J. Kotlikoff. Macroeconomics: An Integrated Approach. South-Western College Publishing, 1995.

[4] Susanto Basu and John G. Fernald. Returns to scale in U.S. production: Estimates and implications. Journal of Political Economy, 105(2):249283, 1997.

[5] Truman F. Bewley. The permanent income hypothesis: A theoretical formulation. Journal of Economic Theory, 16(2):252-292, 1977.

[6] Olivier J. Blanchard. Debt, deficits and finite horizons. Journal of Political Economy, 93(2):223-247, April 1985.

[7] Craig Burnside, Martin Eichenbaum, and Sergio Rebelo. Capital utilization and returns to scale. In Ben Bernanke and Julio Rotemberg, editors, NBER Macroeconomics Annual, pages 67-110. The MIT Press, Cambridge, MA, 1995.

[8] Luis Carranza, Jose E. Galdon-Sanchez, and Jesus Fernandez-Villaverde. Some explorations on entrepeneurship and financial intermediation. Working paper, University of Pennsylvania, 2003.

[9] Ana Castaneda, Javier Díaz-Giménez, and José-Victor Ríos-Rull. Accounting for the U.S. earnings and wealth inequality. Journal of Political Economy, 111(4):818-857, 2003.

[10] V. V. Chari, M. Golosov, and Aleh Tsyvinski. Business start-ups, the lock-in effect, and capital gains taxation. Working paper, University of Minnesota, 2003.

[11] Thomas Cooley, Ramon Marimon, and Vincenzo Quadrini. Aggregate consequences of limited contract enforceability. Mimeo, 2001.

[12] Richard T. Curtin, F. Thomas Juster, and James N. Morgan. Survey estimates of wealth: An assessment of quality. In Robert E. Lipsey and Helen Stone Tice, editors, The Measurement of Saving, Investment and Wealth, volume 52 of Studies in Income and Wealth, pages 473-551. University of Chicago Press, 1989.

[13] Mariacristina De Nardi. Wealth inequality and intergenerational links. Review of Economic Studies. Forthcoming. 
[14] Javier Díaz-Giménez, Vincenzo Quadrini, and José-Victor Ríos-Rull. Measuring inequality: Facts on the distributions of earnings, income and wealth. Mimeo, September 1996.

[15] David S. Evans and Boyan Jovanovic. An estimated model of entrepreneurial choice under liquidity constraints. Journal of Political Economy, 97(4):808-827, August 1989.

[16] David S. Evans and Linda S. Leighton. Some empirical aspects of entrepreneurship. Journal of Political Economy, 79(3):519-535, June 1989.

[17] Stephen M. Fazzari, Glenn R. Hubbard, and Bruce C. Petersen. Financing constraints and corporate investement. Brookings Papers on Economic Activity, 1:141-195, 1988.

[18] William M. Gentry and R. Glenn Hubbard. Entrepreneurship and household savings. Mimeo, February 1999.

[19] Mark Gertler. Government debt and social security in a life-cycle economy. Carnegie-Rochester Conference Series on Public Policy, 50:61-110, 1999.

[20] Douglas Gollin. Getting income shares right. Journal of Political Economy, 110(2):458-474, 2002.

[21] Bronwyn Hall. Investment and research and development at the firm level: Does the source of financing matter? NBER working paper 4096, 1992.

[22] Douglas Holtz-Eakin, David Joulfaian, and Harvey S. Rosen. Entrepreneurial decisions and liquidity constraints. Rand Journal of Economics, 25(2):334-347, 1994.

[23] Douglas Holtz-Eakin, David Joulfaian, and Harvey S. Rosen. Sticking it out: Entrepreneurial survival and liquidity constraints. Journal of Political Economy, 102(1):53-75, 1994.

[24] Mark Huggett. Wealth distribution in life cycle economies. Journal of Monetary Economics, 38:469-494, 1996.

[25] Erik Hurst and Annamaria Lusardi. Liquidity constraints, wealth accumulation and entrepreneurship. Mimeo, December 2001. 
[26] F. Thomas Juster, James P. Smith, and Frank Stafford. The measurement and structure of household wealth. Labour Economics, 6(2):253-275, June 1999.

[27] Timothy Kehoe and David Levine. Debt constrained asset markets. Review of Economic Studies, 60:865-888, 1993.

[28] Laurence Kotlikoff, Kent A. Smetters, and Jan Walliser. Privatizing social security in the US: Comparing the options. Review of Economic Dynamics, 2(3):532-574, July 1999.

[29] Wenli Li. Entrepreneurship and government subsidies: A general equilibrium analysis. Journal of Economic Dynamics and Control, 26:1815-1844, 2002 .

[30] Lee A. Lillard and Robert J. Willis. Dynamic aspects of income mobility. Econometrica, 46:985-1012, 1978.

[31] Tobias J. Moskowitz and Annette Vissing-Jørgensen. The private equity premium puzzle. Mimeo, University of Chicago, 2001.

[32] Vincenzo Quadrini. The importance of entrepreneurship for wealth concentration and mobility. Review of Income and Wealth, 45(1):1-19, March 1999.

[33] Vincenzo Quadrini. Entrepreneurship, saving, and social mobility. Review of Economic Dynamics, 3(1):1-40, 2000.

[34] Nancy L. Stokey and Sergio Rebelo. Growth effects of flat-tax rates. Journal of Political Economy, 103:519-550, 1995.

[35] Kjetil Storesletten, Chris Telmer, and Amir Yaron. Asset pricing with idiosyncratic risk and overlapping generations. Mimeo, June 1999.

[36] Kjetil Storesletten, Chris Telmer, and Amir Yaron. Risk sharing over the life cycle: Genes or luck in the labor market. Mimeo, July 1999.

[37] George Tauchen and Robert Hussey. Quadrature-based methods for obtaining approximate solutions to nonlinear asset pricing models. Econometrica, 59:371-396, March 1991. 
[38] Menahem Yaari. Uncertain lifetime, life insurance, and the theory of the consumer. Review of Economic Studies, 32:137-150, April 1965.

\section{A Income and entrepreneurial ability processes}

As explained in section 3.7, we assume that the income process is $\operatorname{AR}(1)$, and approximate it with a five point discrete Markov chain, using the method described in Tauchen and Hussey [37]. We use an autocorrelation coefficient of .95 (in line with the high persistence found in many microeconomic estimates, such as Storesletten et al. [35]), and choose the variance to match the Gini coefficient of earnings of .38. The resulting gridpoints $y$ for the income process (normalized to an average of 1) are:

$$
\left[\begin{array}{lllll}
0.2468 & 0.4473 & 0.7654 & 1.3097 & 2.3742
\end{array}\right]
$$

and the transition matrix $P_{y}$ is:

$$
\left[\begin{array}{lllll}
0.7376 & 0.2473 & 0.0150 & 0.0002 & 0.0000 \\
0.1947 & 0.5555 & 0.2328 & 0.0169 & 0.0001 \\
0.0113 & 0.2221 & 0.5333 & 0.2221 & 0.0113 \\
0.0001 & 0.0169 & 0.2328 & 0.5555 & 0.1947 \\
0.0000 & 0.0002 & 0.0150 & 0.2473 & 0.7376
\end{array}\right]
$$

We assume that the entrepreneurial ability process is uncorrelated with the income process. The two values for ability $\theta$ are 0 (meaning no entrepreneurial ability) and a positive value (.55), and the transition matrix $P_{\theta}$ is

$$
\left[\begin{array}{cc}
.955 & .045 \\
.21 & .79
\end{array}\right]
$$

$\theta$ and $P_{\theta}$ are calibrated as explained in section 3.7.

\section{B The algorithm}

The algorithm proceeds as follows.

- Construct a grid for the state variables. The maximum asset level is chosen so that it is not binding for the household's saving decisions. 
- Fix an interest rate $r$ and wage rate $w$. Taking $r$ and $w$ as given, solve for the value functions using value function iteration.

- Construct the transition matrix $M$. Compute the associated invariant distribution of wealth, starting from a guess $\pi$ and iterating on $\pi^{\prime}=M \pi^{\prime}$ until $\left(\pi^{\prime}-\pi\right)$ is smaller than a given convergence criterion.

- Compute total savings and total capital invested in the entrepreneurial sector implied by the invariant distribution. Total capital invested by the non-entrepreneurial sector is given by the difference between total savings and total capital invested by the entrepreneurs.

- Compute $r$ and $w$ implied by the above quantities and the non-entrepreneurial aggregate production function, update the wage and interest rate used to solve the problem and iterate until convergence on the factor prices is reached.

The computation of the value functions is non standard because of the presence of the endogenous borrowing constraints. For each state $x$, the endogenous borrowing constraint specifies a maximum amount $\hat{k}(x)$ that an entrepreneur can borrow. The specific function $\hat{k}$ depends however on the value functions themselves. In the algorithm we exploit the fact that, for a given set of state variables, if an entrepreneur runs away with a given level of capital $\tilde{k}$, he would also run away with any $\tilde{k}+\epsilon$, where $\epsilon \geq 0$. We adopt the following algorithm: initialize $\hat{k}(x)=k_{\max }$, the maximum investment level in the economy. We solve the value functions, iterating until convergence, conditional on this borrowing constraint. For each value of $x$, we compare the value function associated with remaining an entrepreneur and repaying the debt with the value function associated with default; we find the maximum level of investment (and borrowing) for which the entrepreneur would not default and set the new $\hat{k}(x)$ to this new value, and compute again the value functions conditional on this updated constraint. This procedure is iterated until $\hat{k}$ does not change across iterations.

As we do not constrain the $\hat{k}(x)$ functions to be decreasing when we iterate on them, we are not imposing convergence. Together with the initialization of these functions at the maximum possible level of borrowing, this implies that if the model has more than one solution, and if the algorithm converges monotonically, then we converge to the "best" solution, i.e. the one that allows 
for the borrowing in the economy. In all of our simulations the algorithm did converge monotonically. 